\title{
Serum Kisspeptin and Its Relation to Metabolic Parameters and Glucose Metabolism in Prepubertal and Pubertal Obese Children
}

\author{
Kochakorn Sithinamsuwan, ${ }^{1}$ Pat Mahachoklertwattana, ${ }^{1}$ Somboon Wankanit, \\ Suwannee Chanprasertyothin, ${ }^{2}$ Sarunyu Pongratanakul, ${ }^{1}$ \\ Patcharin Khlairit, ${ }^{1}$ and Preamrudee Poomthavorn $\mathbb{D}^{1}$ \\ ${ }^{1}$ Department of Pediatrics, Faculty of Medicine Ramathibodi Hospital, Mahidol University, Bangkok 10400, Thailand \\ ${ }^{2}$ Research Center, Faculty of Medicine Ramathibodi Hospital, Mahidol University, Bangkok 10400, Thailand \\ Correspondence should be addressed to Preamrudee Poomthavorn; preamrudee.poo@mahidol.ac.th
}

Received 4 August 2020; Revised 31 October 2020; Accepted 2 November 2020; Published 11 November 2020

Academic Editor: Faustino R. Perez-Lopez

Copyright (C) 2020 Kochakorn Sithinamsuwan et al. This is an open access article distributed under the Creative Commons Attribution License, which permits unrestricted use, distribution, and reproduction in any medium, provided the original work is properly cited.

\begin{abstract}
Objective. Kisspeptin, a puberty control neuropeptide, has been discovered to have an additional role in metabolism and glucose homeostasis regulation. This study aimed to determine the association of serum kisspeptin with metabolic parameters and glucose metabolism in obese children. Design, Patients and Measurements. A cross-sectional study of 270 obese children was conducted. All children underwent an oral glucose tolerance test and had serum kisspeptin, glycated hemoglobin (HbA1c), and lipid profile measurements. Body fat mass was assessed by bioelectrical impedance analysis. Serum kisspeptin levels of both prepubertal and pubertal children with two HbAlc ranges, $<5.7 \%$ (normal range) and 5.7-6.4\% (prediabetes range), were analyzed and correlated with metabolic parameters and glucose metabolism status. Results. The median (IQR) serum kisspeptin level of only pubertal (not prepubertal) children with prediabetes HbA1c was higher than those with normal HbA1c $(53.2(33.9,69.8)$ and 37.8 (29.6, 67.5) $\mathrm{pg} / \mathrm{mL} ; p=0.015$, respectively). There were no differences in serum kisspeptin levels among children with different glucose metabolism status. During pubertal progression, serum kisspeptin reached the highest level at Tanner stage II only in obese boys. Additionally, there was a positive correlation between serum kisspeptin and HbAlc after adjusting for puberty $(\beta=12.87$; $p=0.001)$. No correlations between serum kisspeptin and insulin sensitivity indices, insulin secretion indices, lipid profile, blood glucose, as well as percentage of body fat were demonstrated. Conclusions. Serum kisspeptin levels in pubertal obese children with prediabetes HbAlc were greater than those with normal HbA1c. Serum kisspeptin was positively associated with HbA1c, but not with glucose metabolism status.
\end{abstract}

\section{Introduction}

Childhood obesity has been increasing worldwide. It is wellknown to cause metabolic abnormalities, including abnormal glucose tolerance, diabetes mellitus, and dyslipidemia [1]. Pathogenesis of obesity involves a combination of excessive caloric intake, sedentary lifestyle, and the effects of multiple hormones and adipokines that involve body weight and appetite control such as leptin, adiponectin, proopiomelanocortin, prohormone convertase 1 , melanocortin receptor 3 (MC3R), and melanocortin receptor 4 (MC4R) [2]. In the hypothalamus, kisspeptin is a neuropeptide produced by kisspeptin neurons. It plays a pivotal role in the control of pubertal onset by stimulating the secretion of gonadotropinreleasing hormone [3]. Recently, kisspeptin has been demonstrated to have a role in regulating energy balance and glucose metabolism [4-8]. The kisspeptin receptor (Kiss1r) gene knock-out female mice showed greater body weight, adiposity, fasting blood glucose, and the proportion of impaired glucose tolerance, but lower energy expenditure than the controls [5, 6]. Kisspeptin (KISS1) and KISS1R mRNAs were shown to be expressed in human and mouse islet cells [7]. Additionally, exogenous kisspeptin administration increased glucose-induced insulin secretion (GSIS) 
in both human and mouse islets [7], suggesting an important role of KISS1/KISS1R system in controlling islet function.

Adult studies of serum kisspeptin in relation to metabolic parameters and glucose metabolism have shown conflicting results. Several studies demonstrated a positive effect of kisspeptin on glucose metabolism. Negative association between the serum kisspeptin level and body mass index (BMI) was observed in women with polycystic ovary syndrome (PCOS), obese women, postmenopausal women, nondiabetic obese adults, and female adolescents with anorexia nervosa [9-14]. Additionally, the serum kisspeptin level was shown to be negatively associated with insulin resistance in PCOS patients and obese women [9-11]. Furthermore, administration of kisspeptin in young healthy men caused increased GSIS assessed by intravenous glucose tolerance tests, suggesting a beneficial function of kisspeptin in enhancing insulin secretion in humans [15]. However, a study in nondiabetic obese adults reported that serum kisspeptin was inversely associated with an oral glucose tolerance test (OGTT)-derived indices of insulin secretion [13]. Moreover, the circulating kisspeptin level was greater in patients with type 2 diabetes (T2D) as compared with nondiabetic individuals [16].

In children, there is a period of transition through puberty during which insulin sensitivity is physiologically declined [17]. Kisspeptin, which plays a role in puberty initiation and energy balance and metabolism regulation, may be associated with glucose metabolism in obese children. In contrast to adult studies, the serum kisspeptin level was demonstrated to be positively correlated with BMI, waist circumference, and body weight in a group of obese and normal-weight Chinese children [18]. Nevertheless, data on serum kisspeptin levels in obese children and its associations with metabolic parameters and glucose metabolism are limited.

This study aimed to determine serum kisspeptin levels in obese children and study the associations between serum kisspeptin levels and glucose metabolism as well as metabolic parameters.

\section{Materials and Methods}

2.1. Subjects. There were 270 overweight and obese children enrolled. All of them were recruited from the outpatient clinic of the Department of Pediatrics, Faculty of Medicine Ramathibodi Hospital, Mahidol University, Bangkok, Thailand. Inclusion criteria were children with BMI standard deviation scores (SDSs) of greater than 1 according to the World Health Organization (WHO) BMI reference who were at least 10 years old or less than 10 years old but had entered puberty. Children who had syndromic obesity or chronic illness and received medications that interfered with glucose and lipid metabolism were excluded. The study was performed according to the Declaration of Helsinki and was approved by the Ethics Committee of the Faculty of Medicine Ramathibodi Hospital, Mahidol University (MURA2018/977, dated 9 January 2019). Written informed consent was obtained from all participants and their legal guardians.
2.2. Methods. This cross-sectional study collected clinical data including age, sex, pubertal status, weight, height, and waist circumference. Weight and height SDSs were determined using the National Standard Growth Curve Reference of the Ministry of Public Health, Thailand [19]. BMI was calculated by dividing weight (kilograms) by height (meters squared). The BMI SDS was calculated based on the WHO BMI reference [20]. The BMI SDS of greater than 1 to 2 was defined as overweight, and the BMI SDS of greater than 2 was defined as obesity. Waist circumference was measured at midway between the lowest ribs and superior border of the iliac crest with a nonelastic flexible tape. Owing to a lack of reference of waist circumference for Thai children, waist circumference percentile was assessed using the reference of Chinese children [21]. Pubertal status was determined using Marshall and Tanner's method [22, 23].

All patients underwent blood tests that included an OGTT and fasting serum kisspeptin, glycated hemoglobin (HbA1c), C-peptide, and lipid profile. Serum samples for kisspeptin measurement were kept at $-80^{\circ} \mathrm{C}$ until analysis. Body composition analysis was performed using bioelectrical impedance, InBody $720^{\circledR}$ (BioSpace, Seoul, Korea). The SDS of body fat percentage was calculated using the previously published reference [24]. The serum kisspeptin level was measured using enzyme-linked immunosorbent assay (Cloud-Clone Corp., China) with the lower limit of detection of $13 \mathrm{pg} / \mathrm{mL}$. The amount of analyzed plasma and replicates was $100 \mu \mathrm{L}$. The intraassay and interassay coefficients of variation were $<10 \%$ and $<12 \%$, respectively. Plasma glucose and serum insulin levels were measured using hexokinase/glucose-6-phosphate dehydrogenase method and chemiluminescent microparticle immunoassay, respectively. HbA1c measurement was performed using turbidimetric inhibition immunoassay, a certified and standardized method according to the American Diabetes Association guideline [25]. Other laboratory tests were analyzed using a routine automated analyzer.

In order to assess pubertal effects on serum kisspeptin levels, patients were divided into 2 groups according to their pubertal status (prepuberty and puberty). Each group was then divided into two subgroups according to their $\mathrm{HbAlc}$ levels (normal range, $<5.7 \%$, and prediabetes range, 5.7-6.4\%). All data were analyzed and compared between the two subgroups of patients with the same pubertal status. Correlations between serum kisspeptin and other parameters were determined.

2.3. OGTT, Insulin Sensitivity, and $\beta$-Cell Function Assessment. An OGTT was performed at 08:00-09:00 after an 8- to 10-hour overnight fast. After collecting fasting blood samples for glucose and insulin level measurements, glucose solution at a dose of 1.75 grams per kilogram body weight (maximum 75 grams) was given orally within 5 minutes. Plasma glucose and serum insulin levels were then measured at $30,60,90$, and 120 minutes after the ingestion of glucose solution.

Hyperinsulinemia (HI), which indicates insulin resistance, was characterized by having a fasting serum insulin 
level of $\geq 104 \mathrm{pmol} / \mathrm{L}$, a 2 -hour post-OGTT insulin level of $\geq 521 \mathrm{pmol} / \mathrm{L}$, or a maximum insulin level during the OGTT of $\geq 1042 \mathrm{pmol} / \mathrm{L}$ [26]. Impaired fasting glycemia (IFG) was defined as a fasting plasma glucose (FPG) level of 5.6-6.9 $\mathrm{mmol} / \mathrm{L}$, and impaired glucose tolerance (IGT) was defined as a 2-hour plasma glucose level of 7.8-11.0 mmol/L. Diabetes was diagnosed if patients had either an FPG level of $7.0 \mathrm{mmol} / \mathrm{L}$ or greater or a 2-hour plasma glucose level of $11.1 \mathrm{mmol} / \mathrm{L}$ or greater [25].

To evaluate insulin sensitivity, whole-body insulin sensitivity index (WBISI) [27], homeostasis model assessment of insulin resistance (HOMA-IR) [28], and quantitative insulin sensitivity check index (QUICKI) [29] were determined. Insulinogenic index (IGI) and HOMA index (HOMA- $\beta$ ) [30] were calculated for assessment of $\beta$-cell function (insulin secretion). The following formulas were used with FI representing fasting serum insulin and $G$ representing plasma glucose. $\Delta$ glucose $0-30$ and $\Delta$ insulin $0-30$ indicated the increments of glucose and insulin at 30 minutes of the OGTT, respectively:

(i) $\mathrm{WBISI}=10,000 / \sqrt{\mathrm{FPG}}(\mathrm{mg} / \mathrm{dL}) \times \mathrm{FI} \quad(\mu \mathrm{IU} / \mathrm{mL}) \times$ mean $G(\mathrm{mg} / \mathrm{dL}) \times$ mean insulin $(\mu \mathrm{IU} / \mathrm{mL})$

(ii) HOMA-IR $=($ FPG $(\mathrm{mmol} / \mathrm{L}) \times$ FI $(\mu \mathrm{IU} / \mathrm{mL})) / 22.5$

(iii) QUICKI $=1 /(\log$ FI $(\mu \mathrm{IU} / \mathrm{mL})+\log$ FPG $(\mathrm{mg} / \mathrm{dL}))$

(iv) $\mathrm{IGI}=\Delta$ insulin $0-30(\mu \mathrm{IU} / \mathrm{mL}) / \Delta$ glucose $0-30$ $(\mathrm{mg} / \mathrm{dL})$

(v) HOMA $-\beta=(20 \times$ FI $(\mu \mathrm{IU} / \mathrm{mL})) /($ FPG $(\mathrm{mmol} / \mathrm{L})-$ 3.5)

Additionally, the area under the curves (AUC) of plasma glucose and serum insulin was calculated using the trapezoidal method using the plasma glucose and serum insulin levels derived from the OGTT.

2.4. Statistical Analysis. The IBM SPSS Statistics for Windows, version 24.0 (IBM Corp., Armonk, NY, USA), and the STATA/SE for Windows, version 16.0 (StataCorp LLC, Texas, USA), were used for the analysis. Chi-squared tests were used to compare the categorical data. All continuous data were tested for the distribution using the Kolmogorov-Smirnov test. Non-normally distributed data were reported as median and interquartile range (IQR). The Mann-Whitney $U$ test was applied for comparison of continuous data between two groups of patients. Differences among more than two groups were evaluated by the Kruskal-Wallis test. The median regression analysis was performed to determine associations between serum kisspeptin and other parameters. A $p$ value of less than 0.05 was considered statistically significant.

\section{Results}

Median (IQR) age of 270 enrolled patients was 12.1 (10.9, 13.9) years. There were 127 males (47\%) and 143 females (53\%). Most children were pubertal with 106 (39\%) and 138 (51\%) of them having Tanner stages II-III and IV-V, respectively. The remaining 26 children (10\%) were prepubertal. The median (IQR) BMI SDS of all children was $2.5(2.1,2.9)$. Forty-eight patients $(18 \%)$ were overweight, and 222 patients $(82 \%)$ were obese. The majority of children $(N=179,66 \%)$ had a normal HbA1c level of $<5.7 \%$. Ninetyone patients (34\%) had HbAlc levels between 5.7 and 6.4\%, which were the prediabetes levels [25]. With regard to glucose metabolism status, 39 (14\%), $164(61 \%)$, and 67 (25\%) patients had normal glucose tolerance (NGT), HI, and abnormal glucose tolerance (AGT), respectively. Among 67 patients with AGT, 4 patients had T2D, 3 had IFG, and the remaining 60 had IGT. Clinical characteristics and related parameters of all patients and each subgroup of pubertal status according to $\mathrm{HbAlc}$ ranges are shown in Table 1.

The median (IQR) serum kisspeptin level of all patients was $39.5(30.1,67.1) \mathrm{pg} / \mathrm{mL}$. Serum kisspeptin levels were not different between boys and girls (boys: $41.7(29.6,69.7)$, girls: $39.2(30.3,64.0) \mathrm{pg} / \mathrm{mL}, p=0.532)$. In addition, comparing between boys and girls of each Tanner stage, serum kisspeptin levels were not different. Serum kisspeptin levels were greatest in children with Tanner stages II-III (I: 31.4 (28.1, 48.6); II-III: 50.2 (30.7, 68.9); and IV-V: $38.5(29.6,68.5) \mathrm{pg} /$ $\mathrm{mL} ; p=0.015)$. The significantly highest serum kisspeptin level was observed at Tanner stage II in boys ( $p=0.034)$, but the finding was not reproduced in girls (Figure 1). No difference in serum kisspeptin levels was observed between overweight and obese groups $(48.1(31.8,79.8)$ and 38.4 $(29.6,66.2) \mathrm{pg} / \mathrm{mL}$, respectively; $p=0.203)$. Additionally, there was no significant difference in serum kisspeptin levels among three groups of glucose metabolism status (NGT: 41.5 (29.3, 69.7), HI: 38.8 (29.6, 66.0), and AGT: 43.5 (31.7, $72.4) \mathrm{pg} / \mathrm{mL} ; p=0.422$ ). No significant interval changes of serum kisspeptin levels during the OGTT were observed in our pilot study ( 0 minute: 28.6 (27.2, 33.2), 30 minutes: 27.2 (27.0, 33.5), 60 minutes: 28.5 (26.9, 36.3), 90 minutes: 26.8 $(26.8,36.0)$, and 120 minutes: $26.8(26.8,33.5) \mathrm{pg} / \mathrm{mL}$; $p=0.734)$.

Serum kisspeptin levels of children who had prediabetes $\mathrm{HbAlc} \mathrm{levels} \mathrm{were} \mathrm{significantly} \mathrm{higher} \mathrm{than} \mathrm{those} \mathrm{with} \mathrm{normal}$ HbA1c levels $(51.9$ (32.0, 68.4) and $36.7(29.3,64.0) \mathrm{pg} / \mathrm{mL}$; $p=0.023$ ). Although the BMI SDS, waist circumference percentile, and percentage of body fat SDS were comparable between the two HbAlc groups, patients with prediabetes HbAlc had the greater AUC of glucose, degree of insulin resistance, and proportion of children with AGT than those with normal HbA1c. Subgroup analysis according to pubertal status showed greater serum kisspeptin levels in children with prediabetes HbA1c levels only in the pubertal group (53.2 $(33.9,69.8)$ vs $37.8(29.6,67.5) \mathrm{pg} / \mathrm{mL}, p=0.015)$ (Table 1$)$. Notably, these pubertal children with two different HbA1c ranges had no differences in the BMI SDS, waist circumference percentile, and percentage of body fat SDS. Moreover, pubertal children with prediabetes $\mathrm{HbAlc}$ levels had the higher AUC of glucose and insulin, degree of insulin resistance, and proportion of patients with AGT than pubertal children with normal HbAlc. However, there was no significant difference in IGI, an index of first-phase insulin secretion [31]. In contrast with the findings in pubertal children, such findings were not demonstrated in the group of prepubertal children. Subgroup analysis of pubertal children 
TABLE 1: Clinical characteristics and related parameters of all patients and each subgroup of pubertal status according to HbA1c.

\begin{tabular}{|c|c|c|c|c|c|c|c|c|c|}
\hline \multirow[b]{2}{*}{$\begin{array}{l}\text { Characteristics/ } \\
\text { parameters }\end{array}$} & \multicolumn{3}{|c|}{ All $(N=270)$} & \multicolumn{3}{|c|}{ Prepuberty $(N=26)$} & \multicolumn{3}{|c|}{ Puberty $(N=244)$} \\
\hline & $\begin{array}{l}\text { Normal HbA1c } \\
\qquad(N=179)\end{array}$ & $\begin{array}{c}\text { Prediabetes } \\
\text { HbA1c } \\
(N=91)\end{array}$ & $\underset{\text { value* }^{*}}{p}$ & $\begin{array}{l}\text { Normal HbA1c } \\
\qquad(N=17)\end{array}$ & $\begin{array}{c}\text { Prediabetes } \\
\text { HbA1c } \\
(N=9)\end{array}$ & $\underset{\text { value }^{\dagger}}{p}$ & $\begin{array}{c}\text { Normal } \\
\text { HbA1c } \\
(N=162) \\
\end{array}$ & $\begin{array}{c}\text { Prediabetes } \\
\text { HbAlc }(N=82)\end{array}$ & $\underset{\text { value }^{\ddagger}}{p}$ \\
\hline Age (years) & $12.7(11.1,14.5)$ & $\begin{array}{c}11.8 \\
(10.7,12.9)\end{array}$ & 0.003 & $\begin{array}{c}11.0 \\
(10.4,11.8)\end{array}$ & $\begin{array}{c}10.7 \\
(10.5,11.7)\end{array}$ & 1.000 & $\begin{array}{c}12.9 \\
(11.3,14.8)\end{array}$ & $11.9(10.8,13.1)$ & 0.002 \\
\hline $\begin{array}{l}\text { Male/female, } \\
N(\%)\end{array}$ & $82 / 97(46 / 54)$ & $\begin{array}{l}45 / 46(49 / \\
51)\end{array}$ & 0.571 & $16 / 1(94 / 6)$ & $7 / 2(78 / 22)$ & 0.268 & $\begin{array}{c}66 / 96(41 / \\
59)\end{array}$ & $38 / 44(46 / 54)$ & 0.403 \\
\hline Weight SDS & $4.9(3.2,6.0)$ & $4.4(3.8,6.1)$ & 0.533 & $2.9(2.5,3.9)$ & $3.9(3.2,5.6)$ & 0.029 & $\begin{array}{c}5.0(3.4 \\
6.1)\end{array}$ & $4.5(3.8,6.3)$ & 0.876 \\
\hline Height SDS & $0.9(0.1,1.8)$ & $1.3(0.4,2.3)$ & 0.039 & $0.4(-0.3,1.4)$ & $1.1(0.5,1.5)$ & 0.178 & $\begin{array}{c}1.0(0.1 \\
1.9)\end{array}$ & $1.3(0.4,2.3)$ & 0.066 \\
\hline BMI SDS & $2.6(2.1,2.9)$ & $2.5(2.2,2.9)$ & 0.834 & $2.6(2.3,2.9)$ & $2.6(2.3,3.2)$ & 0.609 & $\begin{array}{l}2.6(2.1 \\
2.9)\end{array}$ & $2.5(2.1,2.9)$ & 0.917 \\
\hline $\begin{array}{l}\text { Waist } \\
\text { circumference } \\
\text { percentile }\end{array}$ & $128(114,148)$ & $\begin{array}{c}127(116, \\
151)\end{array}$ & 0.473 & $115(101,120)$ & $\begin{array}{c}116(102, \\
131)\end{array}$ & 0.293 & $\begin{array}{c}130(115, \\
150)\end{array}$ & $129(118,151)$ & 0.658 \\
\hline $\begin{array}{l}\text { Body fat } \\
\text { percentage SDS }\end{array}$ & $3.3(2.7,4.1)$ & $3.4(2.7,4.0)$ & 0.609 & $3.5(3.3,3.8)$ & $3.6(3.2,4.0)$ & 0.841 & $\begin{array}{c}3.2(2.6 \\
4.1)\end{array}$ & $3.4(2.6,4.0)$ & 0.642 \\
\hline $\begin{array}{l}\text { Kisspeptin (pg/ } \\
\mathrm{mL} \text { ) }\end{array}$ & $36.7(29.3,64.0)$ & $\begin{array}{l}51.9(32.0 \\
\quad 68.4)\end{array}$ & 0.023 & $34.3(27.4,50.9)$ & $\begin{array}{c}30.8(28.7 \\
45.4)\end{array}$ & 0.893 & $\begin{array}{c}37.8(29.6 \\
67.5)\end{array}$ & $53.2(33.9,69.8)$ & 0.015 \\
\hline $\begin{array}{l}\text { C-peptide (nmol/ } \\
\text { L) }\end{array}$ & $1.2(0.9,1.4)$ & $1.3(1.0,1.6)$ & 0.021 & $0.8(0.7,1.3)$ & $1.1(0.7,1.2)$ & 0.586 & $\begin{array}{l}1.2(0.9 \\
1.4)\end{array}$ & $1.3(1.0,1.7)$ & 0.018 \\
\hline HbAlc (\%) & $5.4(5.2,5.5)$ & $5.9(5.8,6.1)$ & $<0.001$ & $5.4(5.2,5.5)$ & $5.8(5.7,6.0)$ & $<0.001$ & $\begin{array}{c}5.4(5.1 \\
5.5)\end{array}$ & $5.9(5.8,6.1)$ & $<0.001$ \\
\hline $\begin{array}{l}\text { Fasting plasma } \\
\text { glucose }(\mathrm{mmol} / \mathrm{L})\end{array}$ & $4.4(4.3,4.7)$ & $4.6(4.3,4.9)$ & 0.153 & $4.5(4.4,4.7)$ & $4.8(4.6,5.1)$ & 0.025 & $\begin{array}{c}4.4(4.3 \\
4.8)\end{array}$ & $4.5(4.3,4.8)$ & 0.407 \\
\hline $\begin{array}{l}\text { 1-h plasma } \\
\text { glucose }(\mathrm{mmol} / \mathrm{L})\end{array}$ & $7.4(6.6,8.6)$ & $8.4(7.2,9.8)$ & $<0.001$ & $7.9(6.7,9.5)$ & $\begin{array}{c}9.4(6.8 \\
10.2)\end{array}$ & 0.374 & $\begin{array}{c}7.4(6.5 \\
8.5)\end{array}$ & $8.3(7.2,9.7)$ & $<0.001$ \\
\hline $\begin{array}{l}\text { 2-h plasma } \\
\text { glucose }(\mathrm{mmol} / \mathrm{L})\end{array}$ & $6.7(5.7,7.4)$ & $7.3(6.4,8.0)$ & 0.001 & $7.3(6.3,7.6)$ & $6.8(6.3,7.8)$ & 0.978 & $\begin{array}{c}6.7(5.7 \\
7.4)\end{array}$ & $7.3(6.4,8.0)$ & 0.001 \\
\hline $\begin{array}{l}\text { AUC glucose } \\
(\mathrm{h} \bullet \mathrm{mmol} / \mathrm{L})\end{array}$ & $13.9(12.5,15.3)$ & $\begin{array}{c}14.9(13.4, \\
16.9)\end{array}$ & 0.001 & $15.1(14.0,17.0)$ & $\begin{array}{c}15.8(13.6 \\
18.1)\end{array}$ & 0.535 & $\begin{array}{c}13.7(12.4 \\
15.2)\end{array}$ & $14.8(13.2,16.8)$ & 0.001 \\
\hline $\begin{array}{l}\text { Fasting plasma } \\
\text { insulin }(\mathrm{pmol} / \mathrm{L})\end{array}$ & $108(74,152)$ & $\begin{array}{l}120(89 \\
207)\end{array}$ & 0.015 & $81(58,152)$ & $\begin{array}{c}103(55, \\
145)\end{array}$ & 0.609 & $\begin{array}{l}110(75 \\
152)\end{array}$ & $126(90,216)$ & 0.015 \\
\hline $\begin{array}{l}\text { 1-h plasma } \\
\text { insulin }(\mathrm{pmol} / \mathrm{L})\end{array}$ & $820(566,1340)$ & $\begin{array}{c}1070(704 \\
1625)\end{array}$ & 0.019 & $763(501,1582)$ & $\begin{array}{c}1176(425 \\
1715)\end{array}$ & 0.936 & $\begin{array}{l}837(570 \\
1311)\end{array}$ & $\begin{array}{l}1063(726 \\
1611)\end{array}$ & 0.015 \\
\hline $\begin{array}{l}\text { 2-h plasma } \\
\text { insulin }(\mathrm{pmol} / \mathrm{L})\end{array}$ & $826(478,1361)$ & $\begin{array}{l}951(617, \\
1688)\end{array}$ & 0.036 & $954(640,1340)$ & $\begin{array}{c}895(494 \\
1320)\end{array}$ & 0.571 & $\begin{array}{c}754(452 \\
1374)\end{array}$ & $962(634,1717)$ & 0.018 \\
\hline $\begin{array}{l}\text { AUC insulin } \\
(\mathrm{h} \bullet \mathrm{pmol} / \mathrm{L})\end{array}$ & $\begin{array}{l}1581(1031, \\
2269)\end{array}$ & $\begin{array}{c}1864(1188, \\
2785)\end{array}$ & 0.067 & $\begin{array}{c}1678(1057 \\
2811)\end{array}$ & $\begin{array}{l}1344(831 \\
2778)\end{array}$ & 0.686 & $\begin{array}{l}1571(1028, \\
2242)\end{array}$ & $\begin{array}{l}1867(1220 \\
2907)\end{array}$ & 0.035 \\
\hline $\begin{array}{l}\text { Glucose } \\
\text { metabolism } \\
\text { status, } N(\%)\end{array}$ & & & & & & & & & \\
\hline NGT & $30(17)$ & $9(10)$ & & $3(18)$ & $2(22)$ & & $27(17)$ & $7(8)$ & $<0.001$ \\
\hline $\mathrm{HI}$ & $119(66)$ & $45(49)$ & & $12(70)$ & $5(56)$ & 0.717 & $107(66)$ & $40(49)$ & \\
\hline AGT & $30(17)$ & $37(41)$ & $<0.001$ & $2(12)$ & $2(22)$ & & $28(17)$ & $35(43)$ & \\
\hline WBISI & $2.6(1.7,4.0)$ & $2.0(1.2,3.0)$ & 0.006 & $2.4(1.6,4.0)$ & $2.7(1.4,5.5)$ & 0.979 & $\begin{array}{c}2.6(1.7 \\
4.0)\end{array}$ & $2.0(1.2,2.9)$ & 0.004 \\
\hline QUICKI & $0.32(0.31,0.34)$ & $\begin{array}{l}0.32(0.29 \\
0.33)\end{array}$ & 0.009 & $0.34(0.31,0.35)$ & $\begin{array}{c}0.32(0.31 \\
0.37)\end{array}$ & 0.571 & $\begin{array}{l}0.32(0.31 \\
0.34)\end{array}$ & $0.31(0.29,0.33)$ & 0.011 \\
\hline HOMA-IR & $3.2(2.0,4.4)$ & $3.7(2.6,6.5)$ & 0.009 & $2.3(1.8,4.1)$ & $3.3(1.6,4.5)$ & 0.571 & $\begin{array}{c}3.2(2.0 \\
4.6)\end{array}$ & $3.9(2.6,6.8)$ & 0.011 \\
\hline IGI & $2.0(1.3,3.2)$ & $1.8(1.3,3.0)$ & 0.480 & $1.5(1.0,2.2)$ & $1.5(1.3,1.8)$ & 0.893 & $\begin{array}{c}2.2(1.3 \\
3.3)\end{array}$ & $1.8(1.3,3.4)$ & 0.524 \\
\hline НOMА- $\beta$ & $318(201,447)$ & $\begin{array}{l}316(222, \\
527)\end{array}$ & 0.371 & $282(123,449)$ & $\begin{array}{l}245(108 \\
298)\end{array}$ & 0.269 & $\begin{array}{l}318(209 \\
450)\end{array}$ & $320(229,611)$ & 0.172 \\
\hline $\begin{array}{l}\text { Total cholesterol } \\
(\mathrm{mmol} / \mathrm{L})\end{array}$ & $4.5(4.0,5.0)$ & $4.5(4.0,5.0)$ & 0.911 & $4.9(4.3,5.8)$ & $4.8(4.4,5.5)$ & 0.914 & $\begin{array}{c}4.5(3.9 \\
5.0)\end{array}$ & $4.4(4.0,4.9)$ & 0.997 \\
\hline HDL-C (mmol/L) & $1.2(1.0,1.3)$ & $1.1(1.0,1.2)$ & 0.042 & $1.3(1.2,1.4)$ & $1.3(1.1,1.5)$ & 0.686 & $\begin{array}{c}1.1(1.0 \\
1.3)\end{array}$ & $1.1(1.0,1.2)$ & 0.031 \\
\hline
\end{tabular}


TABLE 1: Continued.

\begin{tabular}{|c|c|c|c|c|c|c|c|c|c|}
\hline \multirow[b]{2}{*}{$\begin{array}{l}\text { Characteristics/ } \\
\text { parameters }\end{array}$} & \multicolumn{3}{|c|}{ All $(N=270)$} & \multicolumn{3}{|c|}{ Prepuberty $(N=26)$} & \multicolumn{3}{|c|}{ Puberty $(N=244)$} \\
\hline & $\begin{array}{l}\text { Normal HbA1c } \\
\qquad(N=179)\end{array}$ & $\begin{array}{c}\text { Prediabetes } \\
\text { HbA1c } \\
(N=91)\end{array}$ & $\underset{\text { value* }}{p}$ & $\begin{array}{l}\text { Normal HbA1c } \\
\quad(N=17)\end{array}$ & $\begin{array}{c}\text { Prediabetes } \\
\text { HbA1c } \\
(N=9)\end{array}$ & $\underset{\text { value }^{\dagger}}{p}$ & $\begin{array}{l}\text { Normal } \\
\text { HbAlc } \\
(N=162)\end{array}$ & $\begin{array}{c}\text { Prediabetes } \\
\text { HbA1c }(N=82)\end{array}$ & $\underset{\text { value }^{\ddagger}}{p}$ \\
\hline LDL-C (mmol/L) & $2.9(2.4,3.4)$ & $2.9(2.5,3.5)$ & 0.678 & $3.1(2.7,4.0)$ & $3.1(2.7,3.5)$ & 0.850 & $\begin{array}{c}2.9(2.3 \\
3.4)\end{array}$ & $2.9(2.5,3.5)$ & 0.593 \\
\hline $\begin{array}{l}\text { Triglyceride } \\
(\mathrm{mmol} / \mathrm{L})\end{array}$ & $1.0(0.7,1.5)$ & $1.1(0.9,1.5)$ & 0.093 & $0.8(0.6,1.4)$ & $1.1(0.8,1.6)$ & 0.345 & $\begin{array}{c}1.0(0.7 \\
1.5)\end{array}$ & $1.1(0.9,1.5)$ & 0.158 \\
\hline
\end{tabular}

AGT, abnormal glucose tolerance; AUC, area under the curve; BMI, body mass index; HbAlc, glycated hemoglobin; HDL-C, high-density lipoprotein cholesterol; HI, normal glucose tolerance with hyperinsulinemia; HOMA-IR, homeostasis model assessment of insulin resistance; HOMA- $\beta$, HOMA index; IGI, insulinogenic index; LDL-C, low-density lipoprotein cholesterol; NGT, normal glucose tolerance without hyperinsulinemia; QUICKI, quantitative insulin sensitivity check index; SDS, standard deviation score; WBISI, whole-body insulin sensitivity index. Data are presented as median (IQR); ${ }^{*}$ comparing between all children with normal $\mathrm{HbAlc}$ and prediabetes $\mathrm{HbAlc}$; ${ }^{\dagger}$ comparing between prepubertal children with normal $\mathrm{HbAlc}$ and prediabetes $\mathrm{HbA} 1 \mathrm{c}$; and ${ }^{\ddagger}$ comparing between pubertal children with normal HbAlc and prediabetes HbAlc (Mann-Whitney $U$ test for continuous data and chi-square test for categorical data).

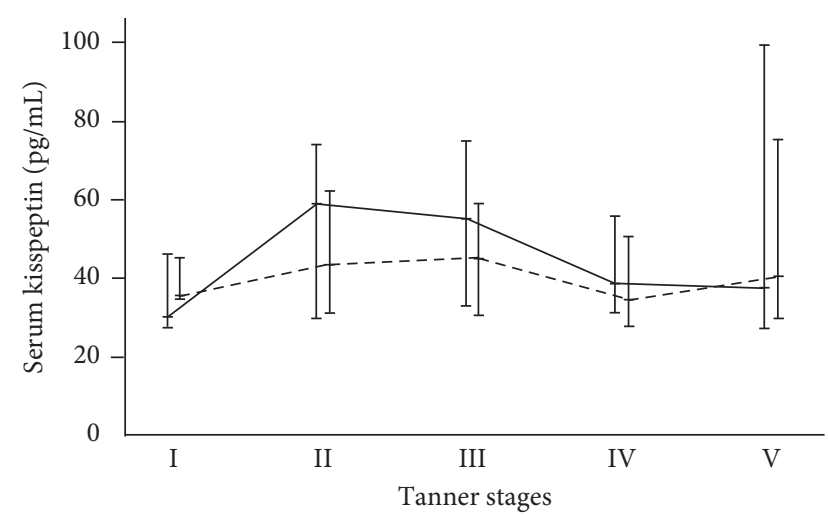

FIgURE 1: Serum kisspeptin levels across 5 genital Tanner stages in boys $(N=127)$ and 5 breast Tanner stages in girls $(N=143)$ ( $p=0.034$ for boys and 0.730 for girls). Error bars represent median (horizontal line) and interquartile range (bar); the solid line represents boys; and the dashed line represents girls.

according to gender revealed no statistically significant difference in serum kisspeptin levels between pubertal children with prediabetes and normal HbAlc ranges in both genders (boys: $58.7(34.3,88.0)$ vs $37.9(29.7,70.4) \mathrm{pg} / \mathrm{mL}, p=0.055$; girls: $50.7(33.3,66.9)$ vs $37.2(28.7,63.3) \mathrm{pg} / \mathrm{mL}, p=0.146)$. However, there was a trend towards higher serum kisspeptin levels in both boys and girls with prediabetes $\mathrm{HbAlc}$ ranges. Small sample size of each subgroup could possibly explain the finding of having no statistically significant difference.

Associations between serum kisspeptin and clinical as well as metabolic parameters are shown in Table 2. Serum kisspeptin was positively associated with Tanner stages II-III $(\beta=18.37, p=0.027)$ and HbAlc $(\beta=14.64, p<0.001)$. After adjusting for puberty, HbAlc remained positively associated with serum kisspeptin $(\beta=12.87, p=0.001)$. No correlations between serum kisspeptin and insulin secretion and insulin sensitivity indices were demonstrated.

\section{Discussion}

To the best of our knowledge, this is the first study that assessed serum kisspeptin levels in a relatively large number of obese children with different HbAlc ranges.
By defining prediabetes state using the $\mathrm{HbAlc}$ level of 5.7-6.4\%, approximately one-third of our obese children would be at high risk for developing diabetes. Our study demonstrated that obese children with prediabetes HbAlc had higher serum kisspeptin levels than those with normal HbAlc. Furthermore, serum kisspeptin was positively associated with $\mathrm{HbAlc}$. In subgroup of pubertal children, higher serum kisspeptin levels were also demonstrated in children with prediabetes $\mathrm{HbA} 1 \mathrm{c}$ levels, while there was no difference in prepubertal children. Pubertal effects on serum kisspeptin could potentially contribute to the difference. However, the limited number of prepubertal children in this study might prevent the identification of significance, if any. Theoretically, children with prediabetes $\mathrm{HbAlc}$ potentially have higher insulin secretion to compensate with insulin resistance. Among pubertal obese children in this study, comparable IGI and HOMA- $\beta$ between those with normal and prediabetes HbAlc may reflect an impairment of first-phase insulin secretion in children with prediabetes HbA1c, which is similar to patients with IFG and IGT [31]. Pubertal obese children with prediabetes HbAlc also had lower insulin sensitivity (lower WBISI and QUICKI, but higher HOMA-IR), but higher total insulin secretion (higher AUC of insulin) as a compensatory mechanism [31], than those with normal HbAlc. Therefore, the finding of greater serum kisspeptin levels in pubertal patients with prediabetes $\mathrm{HbA} 1 \mathrm{c}$ as compared with those with normal HbAlc might be related to the stimulatory effect of kisspeptin on insulin secretion to compensate for insulin resistance. Our findings might be partially supported by previous studies. Obese diabetic rats had a significant increase in hepatic kisspeptin levels as compared with rats without diabetes [8]. Additionally, a previous study in patients with morbid obesity and T2D had decreased serum kisspeptin levels and HbAlc together with decreased insulin secretion and increased insulin sensitivity following Roux-en-Y gastric bypass surgery [32]. Moreover, placental-derived kisspeptin was positively correlated with insulin secretion, suggesting a physiological adaptation to increased insulin resistance during pregnancy [33]. 
TABLE 2: Correlations between serum kisspeptin and other parameters.

\begin{tabular}{|c|c|c|c|}
\hline Parameters & $\beta$-Coefficient & 95\% confidence interval & $p$ value \\
\hline Age & -1.058 & -3.131 to 1.014 & 0.316 \\
\hline Female & -2.520 & -11.656 to 6.616 & 0.588 \\
\hline \multicolumn{4}{|l|}{ Tanner stages } \\
\hline II-III & 18.370 & 2.127 to 34.613 & 0.027 \\
\hline IV-V & 6.810 & -9.057 to 22.678 & 0.399 \\
\hline BMI SDS & -2.584 & -8.024 to 2.856 & 0.350 \\
\hline Waist circumference percentile & 0.057 & -0.094 to 0.208 & 0.457 \\
\hline Body fat percentage SDS & -0.248 & -5.689 to 5.194 & 0.928 \\
\hline C-peptide & 2.707 & -3.415 to 8.830 & 0.384 \\
\hline HbAlc & 14.640 & 6.853 to 22.427 & $<0.001$ \\
\hline Fasting plasma glucose & 4.459 & -4.232 to 13.151 & 0.313 \\
\hline AUC glucose & 0.551 & -1.017 to 2.120 & 0.489 \\
\hline AUC insulin & -0.002 & -0.005 to 0.002 & 0.366 \\
\hline WBISI & 0.944 & -1.175 to 3.062 & 0.381 \\
\hline QUICKI & 57.837 & -68.757 to 184.432 & 0.369 \\
\hline HOMA-IR & -0.139 & -1.561 to 1.282 & 0.847 \\
\hline IGI & -1.662 & -4.368 to 1.045 & 0.228 \\
\hline HOMA- $\beta$ & 0.001 & -0.006 to 0.007 & 0.824 \\
\hline Total cholesterol & -0.310 & -5.973 to 5.353 & 0.914 \\
\hline HDL-C & -17.925 & -35.953 to 0.103 & 0.051 \\
\hline LDL-C & -1.834 & -7.942 to 4.275 & 0.555 \\
\hline Triglyceride & 6.505 & -0.380 to 13.390 & 0.064 \\
\hline
\end{tabular}

AUC, area under the curve; BMI, body mass index; HbAlc, glycated hemoglobin; HDL-C, high-density lipoprotein cholesterol; HOMA-IR, homeostasis model assessment of insulin resistance; HOMA- $\beta$, HOMA index; IGI, insulinogenic index; LDL-C, low-density lipoprotein cholesterol; QUICKI, quantitative insulin sensitivity check index; SDS, standard deviation score; WBISI, whole-body insulin sensitivity index. Correlations were evaluated using median regression analysis.

Despite the fact that individuals with AGT tend to have greater HbA1c as compared with those with NGT, this study only found higher serum kisspeptin levels in patients with prediabetes HbAlc levels as compared with patients with normal $\mathrm{HbAlc}$, while there was no difference in serum kisspeptin levels between patients with AGT and NGT. In fact, $\mathrm{HbAlc}$ reflects average plasma glucose during the past few months, whereas glucose tolerance status reflects plasma glucose response to glucose loading at the time of OGTTs. Therefore, individuals who have AGT status are not identical to those having prediabetes $\mathrm{HbAlc}$. This may explain higher serum kisspeptin levels in patients with prediabetes $\mathrm{HbAlc}$, but not in patients with AGT.

This study did not demonstrate the associations between serum kisspeptin levels and indices of insulin sensitivity and insulin secretion, as well as glucose metabolism status in obese children. These findings were in contrast with those found in previous adult studies that showed association of kisspeptin and insulin sensitivity and GSIS [9-11, 13]. In PCOS women, serum kisspeptin was negatively correlated with HOMA-IR, an index of insulin resistance $[9,10]$. In addition, a study in nonobese and obese women demonstrated a negative correlation between serum kisspeptin and HOMA-IR as well as fasting serum insulin levels [11]. Inverse correlation between serum kisspeptin and IGI was found in nondiabetic obese adults [13]. The difference between the findings of this study and the adult studies could be related to the study population. Abnormal glucose metabolism following the defective kisspeptin signalling was previously demonstrated as age-related emergence in mice studies. In young adult Kiss1r knock-out female mice, their glucose tolerance remained normal despite having increased adiposity $[5,6]$. However, AGT was observed only later in adulthood $[5,6]$. Owing to the fact that the majority of our studied patients were adolescents, associations between serum kisspeptin and indices of insulin sensitivity and insulin secretion as well as abnormal glucose metabolism may not yet be apparent. However, a significant relationship among these parameters might be observed subsequently in their adulthood.

The link between serum kisspeptin and obesity remains conflicting and its mechanism is yet to be elucidated. Previous adult studies demonstrated that serum kisspeptin was negatively associated with $\mathrm{BMI}$ in several population groups [9-14]. In contrast, some studies in both prepubertal and pubertal children showed a higher serum kisspeptin in obese girls as compared with those with normal weight $[18,34]$. Neither significant association between serum kisspeptin and BMI nor significant difference in serum kisspeptin between overweight and obese children was found in this study.

In obese boys, difference in serum kisspeptin during pubertal progression was observed. Serum kisspeptin levels reached maximum at Tanner stage II and then gradually declined thereafter. Such pattern of serum kisspeptin levels during pubertal progression was different from that of Chinese boys whose serum kisspeptin levels continuously increased from Tanner stage I to stage V [18]. The Chinese study included both normal and obese children, whereas this study involved only overweight and obese children. Obesity might influence serum kisspeptin levels during the progression of puberty due to the disturbance of hypothalamic 
kisspeptin by inflammatory cytokines, leptin, insulin resistance, and elevated estrogen secondary to obesity [35].

We acknowledge some limitations of this study. First, healthy control children with normal BMI were not included for comparison. Second, the number of children with T2D was minimal, so the association, if any, could not be demonstrated. Third, the number of pubertal children in the subgroups according to gender was small and the number of prepubertal children was even smaller. Thus, statistical analysis and clinical application could be limited.

\section{Conclusions}

Serum kisspeptin levels in pubertal obese children with prediabetes $\mathrm{HbA1c}$ were greater than those with normal HbA1c. Serum kisspeptin was positively associated with $\mathrm{HbA1c}$, but not with glucose metabolism status and indices of insulin sensitivity and insulin secretion.

\section{Data Availability}

The data that support the findings of this study are available from the corresponding author upon reasonable request.

\section{Conflicts of Interest}

The authors declare that they have no conflicts of interest.

\section{Acknowledgments}

The study was supported by a research grant from the Faculty of Medicine Ramathibodi Hospital, Mahidol University, Bangkok, Thailand (grant number RF_62043, 2019). The authors thank Stephen Pinder, a medical education/ English specialist, for help in proofreading our manuscript.

\section{References}

[1] GBD 2015 Obesity Collaborators, A. Afshin, M. H. Forouzanfar et al., "Health effects of overweight and obesity in 195 countries over 25 years," New England Journal of Medicine, vol. 377, no. 1, pp. 13-27, 2017.

[2] P. W. Speiser, M. C. J. Rudolf, H. Anhalt et al., "Childhood obesity," The Journal of Clinical Endocrinology \& Metabolism, vol. 90, no. 3, pp. 1871-1887, 2005.

[3] L. Pinilla, E. Aguilar, C. Dieguez, R. P. Millar, and M. TenaSempere, "Kisspeptins and reproduction: physiological roles and regulatory mechanisms," Physiological Reviews, vol. 92, no. 3, pp. 1235-1316, 2012.

[4] J. M. Castellano, V. M. Navarro, R. Fernández-Fernández et al., "Changes in hypothalamic KiSS-1 system and restoration of pubertal activation of the reproductive axis by kisspeptin in undernutrition," Endocrinology, vol. 146, no. 9, pp. 3917-3925, 2005.

[5] K. P. Tolson, C. Garcia, S. Yen et al., "Impaired kisspeptin signaling decreases metabolism and promotes glucose intolerance and obesity," Journal of Clinical Investigation, vol. 124, no. 7, pp. 3075-3079, 2014.

[6] K. P. Tolson, C. Garcia, I. Delgado, N. Marooki, and A. S. Kauffman, "Metabolism and energy expenditure, but not feeding or glucose tolerance, are impaired in young Kiss1r KO female mice," Endocrinology, vol. 157, no. 11, pp. 4192-4199, 2016.

[7] A. C. Hauge-Evans, C. C. Richardson, H. M. Milne, M. R. Christie, S. J. Persaud, and P. M. Jones, "A role for kisspeptin in islet function," Diabetologia, vol. 49, no. 9, pp. 2131-2135, 2006.

[8] M. Dudek, P. A. Kołodziejski, E. Pruszyńska-Oszmałek et al., "Effects of high-fat diet-induced obesity and diabetes on Kiss 1 and GPR54 expression in the hypothalamic-pituitary-gonadal (HPG) axis and peripheral organs (fat, pancreas and liver) in male rats," Neuropeptides, vol. 56, pp. 41-49, 2016.

[9] D. Panidis, D. Rousso, G. Koliakos et al., "Plasma metastin levels are negatively correlated with insulin resistance and free androgens in women with polycystic ovary syndrome," Fertility and Sterility, vol. 85, no. 6, pp. 1778-1783, 2006.

[10] N. M. Rashad, R. M. Al-Sayed, M. S. Yousef, and Y. S. Saraya, "Kisspeptin and body weight homeostasis in relation to phenotypic features of polycystic ovary syndrome; metabolic regulation of reproduction," Diabetes \& Metabolic Syndrome: Clinical Research \& Reviews, vol. 13, no. 3, pp. 2086-2092, 2019.

[11] P. A. Kołodziejski, E. Pruszyńska-Oszmałek, E. Korek et al., "Serum levels of spexin and kisspeptin negatively correlate with obesity and insulin resistance in women," Physiological Research, vol. 67, no. 1, pp. 45-56, 2018.

[12] A. Hestiantoro, B. P. K. Astuti, R. Muharam, G. Pratama, F. Witjaksono, and B. Wiweko, "Dysregulation of kisspeptin and leptin, as anorexigenic agents, plays role in the development of obesity in postmenopausal women," International Journal of Endocrinology, vol. 2019, Article ID 1347208, 8 pages, 2019.

[13] F. Andreozzi, G. C. Mannino, E. Mancuso, R. Spiga, F. Perticone, and G. Sesti, "Plasma kisspeptin levels are associated with insulin secretion in nondiabetic individuals," PLoS One, vol. 12, no. 6, Article ID e0179834, 2017.

[14] F. Bacopoulou, G. I. Lambrou, M. E. Rodanaki et al., "Serum kisspeptin concentrations are negatively correlated with body mass index in adolescents with anorexia nervosa and amenorrhea," Hormones (Athens), vol. 16, no. 1, pp. 33-41, 2017.

[15] C. Izzi-Engbeaya, A. N. Comninos, S. A. Clarke et al., "The effects of kisspeptin on $\beta$-cell function, serum metabolites and appetite in humans," Diabetes, Obesity and Metabolism, vol. 20, no. 12, pp. 2800-2810, 2018.

[16] W.-J. Song, P. Mondal, A. Wolfe et al., "Glucagon regulates hepatic kisspeptin to impair insulin secretion," Cell Metabolism, vol. 19, no. 4, pp. 667-681, 2014.

[17] A. Moran, D. R. Jacobs Jr., J. Steinberger et al., "Insulin resistance during puberty: results from clamp studies in 357 children," Diabetes, vol. 48, no. 10, pp. 2039-2044, 1999.

[18] H. J. Zhu, S. J. Li, H. Pan et al., "The changes of serum leptin and kisspeptin levels in Chinese children and adolescents in different pubertal stages," International Journal of Endocrinology, vol. 2016, Article ID 6790794, 11 pages, 2016.

[19] Department of Health, Ministry of Public Health, "Reference for weight, height and nutritional indices in Thais aged 1 day to 19 years," Department of Health, Ministry of Public Health, Bangkok, Thailand, 2000.

[20] World Health Organization, "Growth reference data for 5-19 years,” WHO, Geneva, Switzerland, 2007, https://www.who. int/growthref/en/.

[21] F. Xiong, S. P. Garnett, C. T. Cowell et al., "Waist circumference and waist-to-height ratio in Han Chinese children 
living in Chongqing, south-west China," Public Health $\mathrm{Nu}$ trition, vol. 14, no. 1, pp. 20-26, 2011.

[22] W. A. Marshall and J. M. Tanner, "Variations in the pattern of pubertal changes in boys," Archives of Disease in Childhood, vol. 45 , no. 239 , pp. 13-23, 1970.

[23] W. A. Marshall and J. M. Tanner, "Variations in pattern of pubertal changes in girls," Archives of Disease in Childhood, vol. 44, no. 235, pp. 291-303, 1969.

[24] H. D. McCarthy, T. J. Cole, T. Fry, S. A. Jebb, and A. M. Prentice, "Body fat reference curves for children," International Journal of Obesity, vol. 30, no. 4, pp. 598-602, 2006.

[25] American Diabetes Association, "Classification and diagnosis of diabetes: standards of medical care in diabetes-2020," Diabetes Care, vol. 43, no. Suppl 1, pp. S14-S31, 2020.

[26] G. M. Reaven, Y. D. Chen, C. B. Hollenbeck, W. H. Sheu, D. Ostrega, and K. S. Polonsky, "Plasma insulin, C-peptide, and proinsulin concentrations in obese and nonobese individuals with varying degrees of glucose tolerance," Journal of Clinical Endocrinology \& Metabolism, vol. 76, no. 1, pp. 44-48, 1993.

[27] M. Matsuda and R. A. DeFronzo, "Insulin sensitivity indices obtained from oral glucose tolerance testing: comparison with the euglycemic insulin clamp," Diabetes Care, vol. 22, no. 9, pp. 1462-1470, 1999.

[28] D. R. Matthews, J. P. Hosker, A. S. Rudenski, B. A. Naylor, D. F. Treacher, and R. C. Turner, "Homeostasis model assessment: insulin resistance and $\beta$-cell function from fasting plasma glucose and insulin concentrations in man," Diabetologia, vol. 28, no. 7, pp. 412-419, 1985.

[29] A. Katz, S. S. Nambi, K. Mather et al., "Quantitative insulin sensitivity check index: a simple, accurate method for assessing insulin sensitivity in humans," The Journal of Clinical Endocrinology \& Metabolism, vol. 85, no. 7, pp. 2402-2410, 2000.

[30] M. Albareda, J. Rodríguez-Espinosa, M. Murugo, A. de Leiva, and R. Corcoy, "Assessment of insulin sensitivity and beta-cell function from measurements in the fasting state and during an oral glucose tolerance test," Diabetologia, vol. 43 , no. 12, pp. 1507-1511, 2000.

[31] A. Stancakova, M. Javorský, T. Kuulasmaa, S. M. Haffner, J. Kuusisto, and M. Laakso, "Changes in insulin sensitivity and insulin release in relation to glycemia and glucose tolerance in 6,414 Finnish men," Diabetes, vol. 58, no. 5, pp. 1212-1221, 2009.

[32] C. R. Flynn, V. L. Albaugh, R. A. Tamboli et al., "Roux-en-Y gastric bypass surgery improves hepatic glucose metabolism and reduces plasma kisspeptin levels in morbidly obese patients with type 2 diabetes," American Journal of Physiology-Gastrointestinal and Liver Physiology, vol. 318, no. 2, pp. G370-G374, 2020.

[33] J. E. Bowe, T. G. Hill, K. F. Hunt et al., "A role for placental kisspeptin in $\beta$ cell adaptation to pregnancy," JCI Insight, vol. 4, no. 20, Article ID e124540, 2019.

[34] J. Pita, V. Barrios, T. Gavela-Pérez et al., "Circulating kisspeptin levels exhibit sexual dimorphism in adults, are increased in obese prepubertal girls and do not suffer modifications in girls with idiopathic central precocious puberty," Peptides, vol. 32, no. 9, pp. 1781-1786, 2011.

[35] J. T. George, R. P. Millar, and R. A. Anderson, "Hypothesis: kisspeptin mediates male hypogonadism in obesity and type 2 diabetes," Neuroendocrinology, vol. 91, no. 4, pp. 302-307, 2010. 